\title{
ROLE OF PH, OXIDATION REDUCTION POTENTIAL AND TEMPERATURE CHANGE IN BIOGAS YIELD DURING ANAEROBIC DIGESTION OF CATTLE MANURE
}

\author{
Saeed Samani., Mohammad Ali Abdoli and Abdolreza Karbassi* \\ Environmental Engineering, Faculty of Environment, University of Tehran, \\ Tehran, Iran, No. 25, Ghods St., Enghelab Ave., Tehran, Iran \\ DOI: http://dx.doi.org/10.24327/ijrsr.2017.0803.0083
}

\begin{tabular}{l}
\hline ARTICLE INFO \\
\hline Article History: \\
Received $15^{\text {th }}$ December, 2016 \\
Received in revised form $25^{\text {th }}$ \\
January, 2017 \\
Accepted $23^{\text {rd }}$ February, 2017 \\
Published online $28^{\text {th }}$ March, 2017 \\
\hline
\end{tabular}

Key Words:

Biogas; Cattle Manure; Ph; Orp;

Temperature Change; Anaerobic Digestion

\begin{abstract}
Managing and optimizing biogas yield need to survey quantitatively the effects of parameters on anaerobic digestion. In this research, changes of $\mathrm{pH}$ and oxidation reduction potential (ORP) along with temperature in biogas yield from cattle manure were investigated. The study was carried out by using batch manure mixed 1150-ml anaerobic digester for a duration of 130 days in the mesophilic range $\left(37^{\circ} \mathrm{C}\right)$. Temperature change was also stimulated on the day 45 by decrement from 37 to $25^{\circ} \mathrm{C}$ for one day and then restored to previous condition. Results of biogas yield in different phases showed that the hydrolysis and acetogenic phases occur within 13 days. Biogas production $(76.7 \%)$ occurred within 32 days at $\mathrm{pH}=7.4$ and $\mathrm{ORP}=-358 \mathrm{mV}$. The temperature change stopped biogas yield for 29 days without affecting $\mathrm{pH}$ and ORP values and subsequently after that gas production was restored. Results showed that changes in $\mathrm{pH}$ and ORP were compatible to each other and biogas production. Also temperature change had no significant effect on $\mathrm{pH}$ and ORP but causes delay in the gas production. The results could serve as preliminary criteria for different kinetic analyses and operational guidelines and restoration of the reactors of anaerobic digestion of cattle manure.
\end{abstract}

Copyright (C) Saeed Samani et al, 2017, this is an open-access article distributed under the terms of the Creative Commons Attribution License, which permits unrestricted use, distribution and reproduction in any medium, provided the original work is properly cited.

\section{INTRODUCTION}

Anaerobic digestion is considered as a sustainable solution for the valorization of the organic wastes [1]. Biogas production through anaerobic digestion of cattle manure prevents polluting the environment and produce renewable energy carriers [2]. There are many factors affecting the anaerobic digestion processes [3], including hydraulic retention time (HRT), solid retention time (SRT), organic loading rate (OLR) [4], Oxidation-Reduction Potential (ORP), $\mathrm{pH}$ [5], temperature [6] and nutrient availability [3] and etc.

$\mathrm{pH}$ is one of the factors that affect the production of gas. The $\mathrm{pH}$ value of the slurry in the digester is an important indicator of methane organic performance. Biogas is produced if the $\mathrm{pH}$ is between 6.6 and 7.6. Gas production is highest when the $\mathrm{pH}$ is between 7.0 and 7.2 .Beyond this $\mathrm{pH}$ limits, digestion can proceed but with less efficiency [7]. $\mathrm{pH}$ should be checked periodically during the fermentation. Fluctuation in the $\mathrm{pH}$ can be accommodated through proper control of temperature/ loading rate and adequate mixing [7].

ORP is an indicator of the capacity of the molecules in the wastewater or sludge to release or gain electrons (oxidation or reduction, respectively). Generally, at values greater than +50
$\mathrm{mV}$, aerobic respiration may occur and from +50 to $-50 \mathrm{mV}$, anoxic respiration (denitrification). At values less than-100 $\mathrm{mV}$, not only anaerobic respiration may occur but also we have the production of mixed acids and alcohol fermentation and sulfide removal [8-9]. Methane fermentation starts at values less than-200mV. Usually, However, in a mixed culture of fermenting organisms which exist in an anaerobic digester, methane fermentation or the growth of methane-forming bacteria does not occur until the ORP is less than- $300 \mathrm{mV}$. This is due to the inability of the methane-forming bacteria to successfully compete with other fermenting organisms at values greater than-300mV [8].

Some scientists believe that temperature plays an important role in this biological process and operation [10]. Methaneforming bacteria are strict anaerobes and are extremely sensitive to changes in temperature and $\mathrm{pH}$. There are three ranges of temperature considered in anaerobic digestion which are psychrophilic $\left(<25 \_\right.$C), mesophilic $\left(25-40 \_\right.$C), and thermophilic (>45_C) [11].

Previous studies have investigated the effects of temperature change on the anaerobic digestion process by focusing on the comparison of the performance of reactors at fixed operating temperatures [12-14]. Temperature fluctuations effects, on 
efficiency of anaerobic digestion at certain temperature ranges has been investigated. A short time decrement of temperature (between 10 and 20 C) of psychrophilic anaerobic reactors with swine manure only have had temporary effects on the performance and stability of the process [15].

The effects of temperature on the biogas yields have been investigated by different researchers [16]. Also the effects of temperature shocks on the biogas yields in anaerobic digestion have been studied in different temperature zones [17-19]. Temperature decreases and increases have affected the performance of the bacteria [20]. The fluctuations of temperature on biogas production have been surveyed and results showed that the effect of daily upward of temperature is more than daily downward and it caused more methanogenesis activity [11]. A research showed that one-step temperature increase (from 37 to 55 _C) is better than step-wise increase of temperature from mesophilic to thermophilic operations in anaerobic digestion [21].

To our knowledge, the effect of temperature change on the changes of $\mathrm{pH}$ and ORP has not been yet investigated. Some causes of temperature variations can be controlled (operational conditions) or predicted (environmental conditions in a region) so that the system can be adjusted to accommodate to the new conditions, whereas sudden transient changes can lead to deterioration of the reactor's performance [22, 23].

Furthermore, the purpose of this study was to investigate the changes of $\mathrm{pH}$ and ORP through biogas production and the compatibility of their changes together. Also the effect of temperature change on biogas yield trend and its special related parameters like $\mathrm{pH}$ and ORP was investigated. The result of this study can be used in the operating biogas reactor by setting the time and other parameters and recovering the reactor after a temperature change.

\section{METHODS}

\section{Experimental set-up}

The lab-scale reactor $(1150 \mathrm{~mL})$ was used in this study. The system was equipped with a warm water bath at a temperature of $37 \pm 0.5^{\wedge} \mathrm{C}$.

Fresh cattle manure was used as substrate for every single experiment. This substrate was set to contain total solid of $8 \%$ [24]. Volatile solid was measured to be $85 \%$ of total solid by the method of $2540 \mathrm{E}$ of Standards Methods for the Examination of Water and Wastewater [24].

During the operation of the reactor, no sludge was discharged except for sludge sampling. This test was set for approximately 130 days.

\section{Temperature variations}

The operating temperature was provided and controlled by warm water bath. The main temperature was set in the mesophilic range at a temperature of $37 \pm 0.5^{\wedge} \mathrm{C}$. In phase 1 , the reactor was initially started and after 45 days the temperature changes were simulated by decreasing suddenly from 37 to 25 ${ }^{\wedge} \mathrm{C}$ which lasted for a day. It was adjusted back to the normal operating temperature quickly (within $1 \mathrm{~h}$ ) right after the change time. This change was done to investigate the effect of temperature change on changes of biogas production, $\mathrm{pH}$ and ORP.

\section{Analytical methods}

In order to measure the volume of the biogas production a volumetric gas meter model (Behin Ab G8) was used. It gathers produced bobbles in special container and subsequently it is discharged into a bag. According to the number of emptied container one can measure the time and volume of the produced biogas. It was possible to measure the volume of produced gas on daily basis. In the test the volume of gas was gained in each day. Oxidation Reduction Potential (ORP) and $\mathrm{pH}$ of the samples were measured by a portable multi test device (AZ 86505) on a weekly basis.

\section{RESULTS AND DISCUSSION}

\section{Biogas production trend}

Throughout the 130 days of operation, the biogas production and flux and gas yield rate were measured. Figure 1 shows the trend of biogas production. This figure states that there are some bacterial activity rest which causes risings and fallings in the curve. On the base of these risings and fallings each determined continued rising and falling was considered as a phase. Thus, six operational phases could be distinguished. Phases first to sixth occurred between the days 0-9, 10-13, 14 $45,46-73,74-102$ and 103-130 respectively. Table 1 shows the biogas production in different phases.

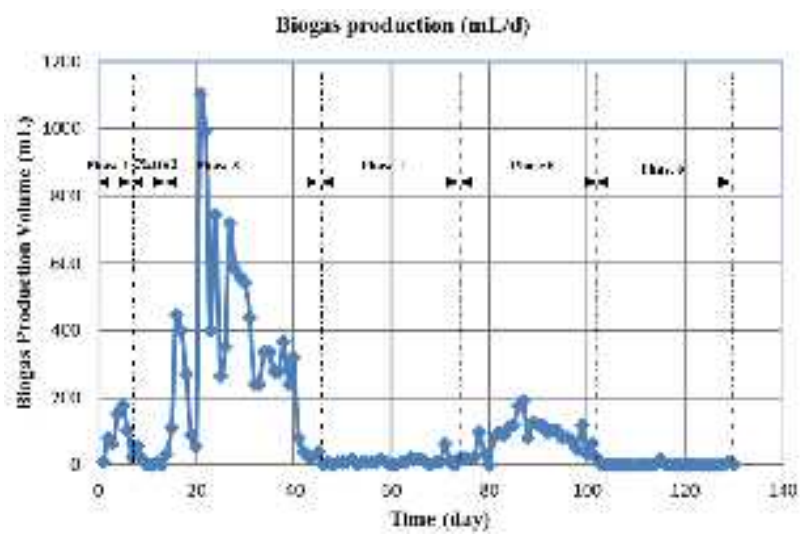

Figure 1 Trend of biogas production

In the phase 1 , there was a rising until the day 4 and falling until the day 9. The maximum volume of biogas is $176 \mathrm{~mL}$ in the day 4 that equals to $4.77 \%$ of total gas production. The duration of phase 2 is about 4 days. Less than $0.06 \%$ of the biogas is produced in this phase and the maximum of the volume is $8 \mathrm{~mL}$. Phase 3 is the most important phase of the process that produce about $76.7 \%$ of biogas. The maximum volume of biogas $(1104 \mathrm{~mL})$ is also produced in this phase and the phase lasts for 32 days.

It should be pointed that temperature change occurred on day 41. Right after the temperature change a falling is happened and for 28 days there was not any gas production (phase 4). During the Phase 5 that lasted for about 29 days, the biogas production equals to about $16.4 \%$. It seems that after the temperature change the system needs 28 days for recovery and then continues to again produce gas. 
Table1 Biogas production in different phases

\begin{tabular}{|c|c|c|c|c|c|c|c|c|}
\hline No. & Phase No. & Day & Time (d) & Volume (mL) & Min.(mL) & Max. (mL) & Average $(\mathrm{mL} / \mathrm{d})$ & Ratio (\%) \\
\hline 1 & 1 & $1-9$ & 9 & 680 & 8 & 176 & 75.56 & 4.77 \\
\hline 2 & 2 & $10-13$ & 4 & 8 & 0 & 8 & 2 & 0.06 \\
\hline 3 & 3 & $14-45$ & 32 & 10960 & 24 & 1104 & 342.5 & 76.7 \\
\hline 4 & 4 & $46-73$ & 28 & 272 & 0 & 64 & 9.71 & 1.9 \\
\hline 5 & 5 & 74-102 & 29 & 2352 & 0 & 192 & 81.1 & 16.4 \\
\hline 6 & 6 & $103-130$ & 28 & 24 & 0 & 16 & 0.85 & 0.17 \\
\hline \multicolumn{2}{|r|}{ total } & $1-130$ & 130 & 14296 & 0 & 1104 & 109.97 & 100 \\
\hline
\end{tabular}

In phase 6 , the least production of gas has happened. More than $97.87 \%$ of the gas has been produced in phases 1, 3 and 5 in 70 days.

\section{pH changes}

As showed in the figure 2, in phase 1, there is a severe reduction in the $\mathrm{pH}$, so the substrate in the reactor could be considered as acidic one specially at the minimum temperature of 6.1. Though in phase 2 a gradual rising in $\mathrm{pH}$ is notce but still it is within acidic range. It was mentioned earlier that for the production of biogas, the $\mathrm{pH}$ value should be set over 7 . In the phase 3 again $\mathrm{pH}$ rises over 7 that means the conditions are suitable for production of biogas. From day 14 till end of the reactor working period, $\mathrm{pH}$ remained between 7- 8 . Therefore, one may conclude that the temperature changes does not affect $\mathrm{pH}$ values.

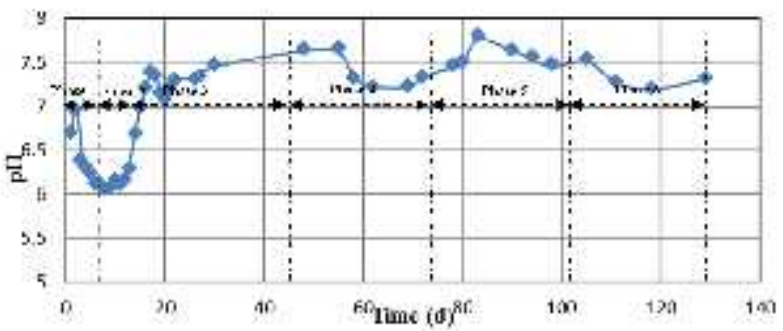

Figure2 Trend of $\mathrm{pH}$ changes

Table $2 \mathrm{pH}$ changes in different phases

\begin{tabular}{ccccccc}
\hline No. & Phase No. & Day & Time $(\mathbf{d})$ & Max. & Min. & average \\
\hline 1 & 1 & $1-9$ & 9 & 7 & 6.1 & 6.3 \\
2 & 2 & $10-13$ & 4 & 6.7 & 6.1 & 6.4 \\
3 & 3 & $14-45$ & 32 & 7.5 & 7.0 & 7.4 \\
4 & 4 & $46-73$ & 28 & 7.7 & 7.2 & 7.4 \\
5 & 5 & $74-102$ & 29 & 7.8 & 7.5 & 7.6 \\
6 & 6 & $103-130$ & 28 & 7.6 & 7.2 & 7.3 \\
\hline
\end{tabular}

\section{ORP changes}

Figure 3 and table 3 show the changes of ORP during the process in the substrate. The ORP in the fresh manure is -320 $\mathrm{mV}$ and after that it is constant in phase 1 . There is a sudden decrease in the early of phase 2 that increase the ORP values to over $-435 \mathrm{mV}$. After that the parameter has no determined trend until early of phase 6 . It shows that phases 3 to 5 have the condition to produce biogas. In the phase 6 the ORP increase to normal condition which means that temperature change has no effect on the ORP and it remains between -318 to-435

Table 4 presents a summary of the results of biogas production, $\mathrm{pH}$ and ORP changes in different phases. As it is showed in the phases 1 and $2 \mathrm{pH}$ is less than 7 and both of them are in acidic phase. Also ORP in these phases are $-320,-322$ respectively and it is not a suitable condition for biogas production.

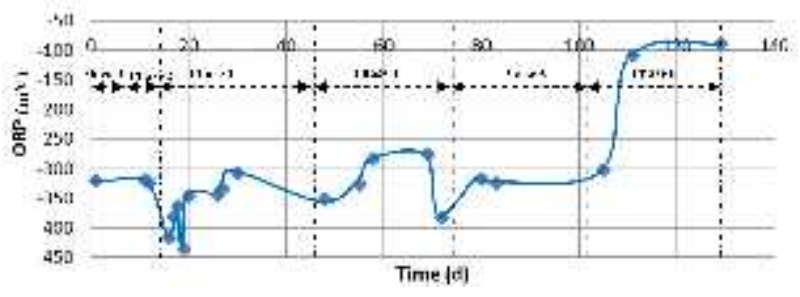

Figure 3 Trend of ORP changes $(\mathrm{mV})$

Table 3 ORP changes in different phases $(\mathrm{mV})$

\begin{tabular}{ccccccc}
\hline No. & Phase No. & Day & Time (d) & Max. & Min. & average \\
\hline 1 & 1 & $1-9$ & 9 & -320 & -320 & -320 \\
2 & 2 & $10-13$ & 4 & -320 & -324 & -322 \\
3 & 3 & $14-45$ & 32 & -320 & -435 & -358 \\
4 & 4 & $46-73$ & 28 & -275 & -383 & -324 \\
5 & 5 & $74-102$ & 29 & -318 & -324 & -321 \\
6 & 6 & $103-130$ & 28 & -89.8 & -303 & -167 \\
\hline
\end{tabular}

It can be inferred that the gas produced in the phase 1 and 2 is the form of soluble form. So, the phase 1 is compatible with hydrolysis phase and phase 2 is compatible with acidogene and acetogene phases.

Table 4 Summary of the results of biogas production, $\mathrm{pH}$ and ORP changes in different phases

\begin{tabular}{ccccccc}
\hline \multirow{2}{*}{ No. Phase No. } & \multirow{2}{*}{ Day } & \multicolumn{2}{c}{ Time (d) $\begin{array}{c}\text { Ratio of biogas Average of } \\
\text { production (\%) }\end{array}$} & $\begin{array}{c}\text { Average of } \\
\text { pH }\end{array}$ & ORP (mV) \\
\hline 1 & 1 & $1-9$ & 9 & 4.77 & 6.3 & -320 \\
2 & 2 & $10-13$ & 4 & 0.06 & 6.4 & -322 \\
3 & 3 & $14-45$ & 32 & 76.7 & 7.4 & -358 \\
4 & 4 & $46-73$ & 28 & 1.9 & 7.4 & -324 \\
5 & 5 & $74-102$ & 29 & 16.4 & 7.6 & -321 \\
6 & 6 & $103-130$ & 28 & 0.17 & 7.3 & -167 \\
\hline
\end{tabular}

In the phases $3-5, \mathrm{pH}$ is more than 7 and the mean of ORP is $358,-324$, and -321 respectively. This condition is suitable for production of biogas. About $95 \%$ of the biogas is produced in this phase. This phase is compatible with methanogene phase. In phase $6, \mathrm{pH}$ is 7.3 and the mean of ORP is -167 . This condition is not suitable with any form of the biogas production.

Temperature change in the day 45 did not change the $\mathrm{pH}$ and ORP but causes a delay in production of the biogas. This might be indicative of shock over methanogene bacteria that eventually can recover within a period of 29 days.

\section{CONCLUSIONS}

On the base of changes in biogas yield, $\mathrm{pH}$ and ORP, it can be concluded that phase 1 is compatible with hydrolysis phase which lasts for 9 days and phase 2 is compatible with acetogene phase which lasts for 4 days. Also phases 3 to 5 is compatible with methanogene phase. $95 \%$ of the biogas is produced in these phases in 89 days and $93.1 \%$ of biogas is produced in 61 days in phases 3 and 5 . 
The temperature of the reactor has an influence on the biogas production. In the mesophilic temperature range, temperature change led to a reduction in the biogas production rate, and recovered for 28 days. Once recovered, the process continued until the end of biogas production. Temperature change has no significant influence on $\mathrm{pH}$ and ORP ranges and both of them have no changes related to previous and next phases compared to that of the standard ranges. However these results indicate that although methanogens are quite sensitive to temperature change (sudden change in temperature and quick restoration) it causes delay in production of biogas without any changes in other parameters which related to rehabilitation of mesophilic bacteria.

\section{Acknowledgement}

The authors should acknowledge Iran National Science Foundation (INSF) for supporting the research.

\section{References}

P. P. Nieto, D. Hidalgo, R. Irusta, D. Kraut, Biochemical methane potential (BMP) of agro-food wastes from the Cider Region (Spain), Water Science \& Technology. 66 (9) (2012) 1842-1848

S. Sakar, K. Yetilmezsoy, E. Kocak, Anaerobic digestion technology in poultry and livestock waste treatment - a literature review, Waste Management and Research. 27 (2009) 3-18

Y. Chen, J. J. Cheng, K. S. Creamer, Inhibition of anaerobic digestion process: a review, Bioresour Technol. 99 (10) (2008) 4044-4064.

K. C. Wijekoon, C. Visvanathan, A. Abeynayaka, Effect of organic loading rate on VFA production, organic matter removal and microbial activity of a two stage thermophilic anaerobic membrane bioreactor, Bioresource Technology. 102 (9) (2011) 5353-5360.

W. J. Gao, H. J. Lin, K. T. Leung, B. Q. Liao, Influence of elevated $\mathrm{pH}$ shocks on the performance of a submerged anaerobic membrane bioreactor, Process Biochemistry. 45 (80) (2010) 1279-1287.

W. Choorit, P. Wisarnwan, Effect of temperature on the anaerobic digestion of palm oil mill effluent, Electronic Journal of Biotechnology. 10 (3) (2007) 376-385.

P. A. Ukpai, G. F. Ibeh, P. E. Agbo, C. A. Elekwa, Effect of $\mathrm{pH}$ on the volume of gas produced from cowpea, cassava peeling, Journal of Physical Sciences and Innovation. 3 (2011) 44-49.

M. Gerardi, the Microbiology of Anaerobic Digesters, $1^{\text {st }}$ edition, John Wiley \& Sons Inc., 2003.

Z. Li, Q. Song, D. Wang, J. Zhang, J. Xing, A novel up-flow inner-cycle anoxic bioreactor (UIAB) system for the treatment of sulfide wastewater from purification of biogas, Water Science \& Technology. 65 (6) (2012) 1033-1040.

W. J. Gao, K. T. Leung, W. S. Qin, B. Q. Liao, Effects of temperature and temperature shock on the performance and microbial community structure of a submerged anaerobic membrane bioreactor, Bioresource Technology. 102 (19) (2012) 8733-8740.
H. M. El-Mashad, G. Zeeman, W. K. Van Loon, G. P. Bot, G. Lettinga, Effect of temperature and temperature fluctuation on thermophilic anaerobic digestion of cattle manure, Bioresource Technology. 95 (2) (2004) 191-201.

M. Kim, Y. H. Ahn, R. E. Speece, Comparative process stability and efficiency of anaerobic digestion; mesophilic vs. thermophilic, Water Research. 36 (17) (2002) 4369-4385.

P. M. Ndegwa, D. W. Hamilton, J. A. Lalman, H. J. Cumba, Effects of cycle frequency and temperature on the performance of anaerobic sequencing batch reactors (ASBRs) treating swine waste, Bioresource Technology. 99 (6) (2008) 1972-1980.

T. Yilmaz, A. Yuceer, M. Basibuyuk, A comparison of the performance of mesophilic and thermophilic anaerobic filters treating papermill wastewater, Bioresource Technology. 99 (1) (2008) 156-163.

D. I. Massé, L. Masse, F. Croteau, The effect of temperature fluctuations on psychrophilic anaerobic sequencing batch reactors treating swine manure, Bioresource Technology. 89 (1) (2003) 57-62.

K. J. Chae, A. Jang, S. K. Yim, I. S. Kim, The effects of digestion temperature and temperature shock on the biogas yields from the mesophilic anaerobic digestion of swine manure, Bioresour Technol. 99 (2008) 1-6.

M. W. Peck, J. M. Skilton, F. R. Hawkes, D. L. Hawkes, Effects of temperature shock treatments on the stability of anaerobic digesters operated on separated cattle slurry, Water Research. 20 (4) (1986). 453-462.

B. K. Ahring, A. A. Ibrahim, Z. Mladenovska, Effect of temperature increase from 55 to 65 _C on performance and microbial population dynamics of an anaerobic reactor treating cattle manure, Water Research. 35 (10) (2001) 2446-2452.

R. Iranpour, F. Alatriste-Mondragon, H. H. Cox, R. T. Haug, Effects of transient temperature increases on odor production from thermophilic anaerobic digestion, Water Science and Technology. 52 (1-2) (2005) 229-235.

J. H. Ahn, C. F. Forster, The effect of temperature variations on the performance of mesophilic and thermophilic anaerobic filters treating a simulated papermill wastewater, Process Biochemistry. 37 (6) (2002) 589-594.

Bouskova, M. Dohanyos, J. E. Schmidt, I. Angelidaki, Strategies for changing temperature from mesophilic to thermophilic conditions in anaerobic CSTR reactors treating sewage sludge, Water Res. 39 (8) (2005) 1481-1488.

S. J. Jahren, J. A. Rintala, The closure of water circuits by internal thermophilic (55 and $70 \_$C) anaerobic treatment in the thermomechanical pulping process, Water Science and Technology. 35 (2-3) (1997) 49-56.

F. Morgan-Sagastume, D. G. Allen, Effects of temperature transient conditions on aerobic biological treatment of wastewater, Water Research. 37 (15) (2003) 3590-601.

American Public Health Association/American Water Works Association/Water Environment Federation, Standard Methods for the Examination of Water and Wastewater, 20th edition, Washington DC. USA, 1998. 